\title{
A Healthy Metaphor? The North Sea Consultation and the Power of Words
}

\author{
Haye Geukes ${ }^{1}$, Udo Pesch ${ }^{2, *(D)}$, Aad Correljé ${ }^{2}(\mathbb{D})$ and Behnam Taebi ${ }^{2}$ (D) \\ 1 Faculty of Science, Institute of Environmental Sciences (CML), Leiden University, 2311 EZ Leiden, \\ The Netherlands; h.h.geukes@cml.leidenuniv.nl \\ 2 Department of Values, Technology and Innovation, Faculty of Technology, Policy and Management, \\ Delft University of Technology, P.O. Box 5015, 2600 GA Delft, The Netherlands; A.F.Correlje@tudelft.nl (A.C.); \\ B.Taebi@tudelft.nl (B.T.) \\ * Correspondence: u.pesch@tudelft.nl
}

Citation: Geukes, H.; Pesch, U.; Correljé, A.; Taebi, B. A Healthy Metaphor? The North Sea Consultation and the Power of Words Sustainability 2021, 13, 12905. https:// doi.org/10.3390/su132212905

Academic Editor: Aled Jones

Received: 22 October 2021

Accepted: 18 November 2021

Published: 22 November 2021

Publisher's Note: MDPI stays neutral with regard to jurisdictional claims in published maps and institutional affiliations.

Copyright: (c) 2021 by the authors. Licensee MDPI, Basel, Switzerland. This article is an open access article distributed under the terms and conditions of the Creative Commons Attribution (CC BY) license (https:// creativecommons.org/licenses/by/ $4.0 /)$.

\begin{abstract}
The North Sea Consultation was set up to resolve conflicting claims for space in the North Sea. In 2020, this consultation process resulted in the North Sea Agreement, which was supported by the Dutch Parliament and cabinet as a long-term policy; however, the fishing sector felt excluded, left the consultation process, and does not support the agreement. Using semi-constructed interviews and the method of wide reflective equilibrium, this research found that in this conflict the metaphor of 'health' has played a decisive role. While all stakeholders want to keep the sea 'healthy', they disagree on what a healthy sea actually means, leading to contrastive positions on the desirability of trawler fishing, wind parks, and conservation areas-the North Sea Agreement's main foci of interest. To prevent the unproductive escalation of such a conflict, it is inevitable to acknowledge the moral connotations of such metaphors, as this allows a decision-making process that can be considered more just.
\end{abstract}

Keywords: North Sea agreement; North Sea consultation; metaphors; ecological health; fishery; offshore wind energy; wicked problems; political negotiation processes

\section{Introduction}

Policy science speaks of 'wicked problems' when there is a diversity of stakeholders that come with different problem definitions, solutions, world views, and so on. According to Rittel and Webber, who coined the notion of wicked problems [1], the plurality of moral positions is a-if not the-defining trait of wicked problems. Nevertheless, this moral character has been consequently underplayed by policy-makers and policy scholars [2], which might be due to the difficulty of finding a common solution to moral plurality-while the raison d'etre of policy is to come up with singular measures. This failure to acknowledge the moral character of wicked problems makes them susceptible to societal contestation and contributes to an increase in public distrust. In other words, it makes a wicked problem even more wicked. As such, we need to study wicked problems as problems that are subject to moral uncertainties [3], highlighting the variety of positions, while asking how this variety can be accommodated in appropriate policies.

Without any doubt, the most wicked of all problems is that of climate change. The questions of how to deal with rising global temperatures and the ensuing environmental and societal effects are saturated with complexity and uncertainty. Additionally, the moral connotations of the problem are often not addressed in the fear of complicating effective decision-making. The upshot, however, is counterproductive moral tribalism [4], where parties do not talk to each other with the aim of overcoming differences but see their own position as the only legitimate one, while other positions are seen as intrinsically bad or even ridiculous. Instead of neglecting the moral connotations of wicked problems, they should be made explicit and become the subject of reflection. To do so, approaches from 
ethical theory can be deployed, such as Rawls's wide reflective equilibrium method [5], which suggests that reasonable citizens can weigh their own and others' considered (moral) convictions, as a result of which a reasonable consensus can emerge.

However, many of these approaches assume that moral judgments can be discussed as analytically independent from contingent factors such as power and language [6]. It can be expected that in the context of wicked problems, language, power, and moral judgments are closely related, as normative preferences about certain solutions are intrinsically intertwined with problem definitions and social positions. As such, it is necessary to develop appropriate tools that also recognize the roles power and language play in morally laden societal contestations. It is the aim of this paper to contribute to the development of the aforementioned tools by studying the impact of language in the Dutch North Sea Consultation (Noordzeeoverleg in Dutch), which aimed to develop an integrated strategy for Dutch national policy on the North Sea up to 2030 that is supported by all stakeholders [7].

This consultation process concerns both climate mitigation and adaptation measures, as it involves not only the development of on-sea wind parks but also the preservation of ecosystems and the economic livelihood of fishers. Combining mitigation and adaptation measures with existing functions requires drastic trade-offs to be made between different kinds of environmental, economic, and social concerns. However, there are deep scientific uncertainties about the efficacy of these measures, and as the conflict with the fishing sector demonstrates, there are profound conflicts that make us believe that the North Sea Consultation could best be considered a wicked problem (cf. [8]). A salient feature of the consultation process is that all stakeholders appeared to agree on the goal of keeping the North Sea healthy and the necessity to adapt all other activities to this goal. However, there seems to be a substantial difference in what they mean by 'healthy'. This raises questions as to what is understood as a 'healthy' North Sea and what the impact is of using this metaphor on the consultation process. The focus of this paper is on the role of metaphors in political decision-making. Section 2 presents the study's methods for researching this. Section 3 will outline our theoretical starting points with regards to this role of metaphors. In Section 4, the case will be introduced, followed by empirical analyses of different concepts of health in the debate in Section 5. Section 6 will critically assess the dominance of the metaphor of health, which leaves no room for other positions.

In the final section, we will reflect on our findings and address how the role of metaphors affects the fairness of a deliberative process. We further provide suggestions for overcoming such potentially problematic issues. We consider these suggestions especially relevant for climate adaptation policy, since this is a field in which metaphors seem to be powerful tools. A thorough scrutiny of the implications of metaphors is very much needed.

\section{Methods}

This research started as explorative desk research to identify normative uncertainties in the North Sea Consultation. To construct a timeline on events relevant to this consultation and find potential topics of moral conflict, we searched for 'Noordzeeakkoord', 'Noordzee akkoord', 'Overleg voor de Noordzee', and 'Noordzeeoverleg', two ways of writing North Sea Agreement and North Sea Consultation in Dutch, respectively, on the websites of the five largest Dutch newspapers, two national news magazines, and the public archive of the Dutch national government until 14 April 2021. In line with the definition of normative uncertainties by Taebi et al. [3], the articles were scanned for potential topics of moral disagreement on the criterium that they support a proposed course of action on which stakeholders disagree, and which is at least minimally morally defensible. Nine topics met this criterium, as listed in Appendix A (Table A1).

To gather stakeholders' moral views, semi-constructed interviews were held between March and June 2021 with 8 of the 15 original participants of the consultation, a list of whom can be found in Appendix B (Table A2). The interviews were structured around the list of topics set up in the first explorative phase of this study, while remaining open for new topics and views by asking open questions, sending interviewees the list of topics 
at least a week before the interview took place, and leaving space for the interviewees to bring up what they think might be relevant to the study. Due to COVID-19 measures, most interviews were held online via Microsoft Teams or Zoom and video-recorded. The chair of the Dutch Fishers' Union (Nederlandse Vissersbond in Dutch) was interviewed in person, in Urk, and was audio-recorded on the first author's smartphone. The recordings were stored on this author's personal device, transcribed to text by hand, and color-coded. For quotations, the text was translated to English while aiming to maintain any informal character it had. All interviewees signed a consent form on the storage and use of interview and personal data and were able to review and adjust quoted text. In cases of new data usage, consent was asked for again.

\section{The Moral Role of Metaphors}

The field of cognitive linguistics helps to understand how concepts and concepts relate and are used in society. The field was initiated by Lakoff and Johnson [9] in the 1980s [10], who analyzed the perception and communication of concepts. These authors argue that people often understand or communicate abstract concepts metaphorically, i.e., they use one concept to refer to another. Often, this involves an intuitively felt concept that is used to understand or communicate a more abstract one. For instance, in the metaphors 'time is money', 'love is a journey', or 'argument is war', the abstract concepts 'time', 'love', and 'argument' are depicted as physical and intuitive by representing them by 'money', 'journey', and 'war'. As people do not easily grasp the meaning of abstract and complex concepts, they employ concepts that they intuitively feel to 'make more sense'. This allows part of that abstract concept to be seen in the light of what is felt intuitively, so its concept can more easily be discussed and understood.

Using different metaphors implies the communication of different understandings and moral beliefs. Metaphors inform us how to perceive a certain phenomenon, but also inform us about which actions are possible and which ones are desirable. As Lakoff and Johnson [9] argue, metaphors could either hide or open up possible ways of understanding a concept or phenomenon, and in this way alter the normative judgments about it. Indeed, as Foucault argued, language equals power and one cannot overestimate its influence on our moral views. In addition, we cannot hold moral views without language; there is no way to construct an idealized deliberative process based on genuine moral truths, as both deliberation and morality are intrinsically linguistic phenomena. It is also hard to think about a language without metaphors. Even if that could be possible, the realm of climate politics is already portraying many such metaphors. In fact, the notion of 'climate adaptation' is intrinsically metaphoric, as it pertains to a wide range of activities that are connected to an equally wide range of the consequences of climate change. The notion of climate adaptation reduces this enormous plurality and heterogeneity of measures and events within a single term, enabling governments to effectively develop and legitimize policies. Moreover, 'climate adaptation' invokes a long list of similar metaphors such as 'resilience', 'systems', or 'vulnerability', which are all terms that help us to make sense of a wide variety of phenomena while predefining our scope of action [11]. For instance, in the IPCC's definition of resilience, at least half the terms are metaphorical, i.e., "The ability of a system and its component parts to anticipate, absorb, accommodate, or recover from the effects of a hazardous event in a timely and efficient manner" [12] (our italics added). Indeed, to make sense of climate adaptation is to use metaphors, and as such these deserve to be analyzed in more detail.

The health metaphor is commonly used in environmental sciences and by major institutions. As a concept related to the human body, 'health' makes sense in a direct manner, and as such it is a concept from which courses of action are felt to follow logically. Indeed, all people want to protect and maintain their health. Ross et al. [13] argue how 'health' as a metaphor for a certain desired state is especially emotionally and politically powerful. Feeling ill - the opposite of being healthy-is a universal experience, the authors write, a situation that all people wish to avoid. It is, thus, something that all people can 
relate to and to which all people hold an immediate normative standpoint. Being ill is detested and being healthy is cherished, on a universal but also most intimate level.

In an environmental context, this understanding of 'health' in respect of the environment refers to it being in a good state [14]. Often, 'environmental health' is used to refer to the state of an ecosystem, a concept which in itself can again have multiple meanings or perspectives, as Ross et al. [13] describe. In conceptualizing what exactly is referred to when one speaks of a 'healthy ocean', Franke et al. [15] conclude that 'health' refers to a 'pre-analytic vision' of a good state of the ocean. Karr [16] came to a similar conclusion, stating that the metaphor of health in an environmental context refers to a 'good condition', which should be looked at in more specificity and detail to understand what exactly entails this state of being 'good'.

The health metaphor is commonly used by environmental scientists to call policymakers to action $[17,18]$. For instance, this can be seen in SDG 14 of the United Nations, as Franke et al. [15] state. This speaks of the aim to 'achieve healthy oceans' and 'improve ocean health', although is difficult to operationalize, as Cormier and Elliot [17] argue. It is difficult to determine what 'health' means in this context, as Halpern [19] describes. Franke et al. [15] argue that the roots for the SDG's operationalization challenges lie in the use of the metaphor of 'ocean health', as this brings about specific points of view that might apply to a body but not necessarily to an ecosystem.

\section{The Case of the North Sea Consultation}

The North Sea Consultation was initiated by non-governmental parties in the Netherlands in 2018. This consultation pursued the goal of increasing the production capacity of wind parks on the North Sea, as required by the Dutch climate policy, which aims to expand this capacity up to 60 -fold by 2050 compared to 2017 . This entails increasing the number of wind turbines from 289 to 2500-7500 [20], which will then come to cover about one-fifth of the Dutch Exclusive Economic Zone in the North Sea [21]. As almost all space in the North Sea already serves one or more usage functions, the consultation was set up to deal with conflicting claims for space.

Market parties aimed to reduce conflicts about space they would otherwise have. Additionally, the coordinating minister of Infrastructure and Water Management (I\&W), Van Nieuwenhuizen-Wijbenga, asked Jacques Wallage, the co-chair of the Physical Environment Consultative Council (in Dutch: Overlegorgaan Fysieke Leefomgeving, OFL), for advice on how to manage the space allocation in the North Sea in a fair way, by finding support from the stakeholders and the relevant departments [22]. This platform should facilitate the decision-making between these departments. As some interviewees mentioned, they operated as non-connected 'silos'. Now, they have to make their decisions together.

In December 2018, Wallage advised the minister to set up the North Sea Consultation such that all stakeholders could participate in the decision-making, instead of just being consulted [7,22]. The minister followed his advice in February 2019, so that the "most important societal parties" and the governmental departments could come together to resolve and prevent conflicts [22]. The three main sectors in the North Sea were decided to be the fisheries, nature preservation, and the energy sector [23]. Therefore, in the North Sea Consultation, governmental and non-governmental parties together were expected to create consensus on integrated long-term plans for using space in the North Sea.

Table 1 lists the 15 parties that had a seat at the start of the North Sea Consultation. These parties were represented by their main executives, as the OFL requested. The Royal Netherlands Academy of Arts and Sciences (KNAW) served as a scientific advisor [6]. 
Table 1. Participants in the North Sea Consultation.

\begin{tabular}{cc}
\hline Sector & Actor \\
\hline \multirow{3}{*}{ Government } & Ministry of Infrastructure and Water Management (I\&W) \\
& Ministry of Agriculture, Nature, and Food Quality (LNV) \\
Ministry of Economic Affairs and Climate Policy (EZK) \\
NOGEPA (branch association for the energy sector) \\
NWEA (branch association for the wind sector) \\
EBN (coordinator of Dutch energy policy) \\
TenneT (distribution system operator) \\
VisNed (branch association for cutter fishers) \\
Fishery & Nederlandse Vissersbond (branch association for the fishing sector) \\
& Stichting de Noordzee (North Sea Foundation) \\
Wereld Natuur Fonds (World Wildlife Fund) & Greenpeace \\
Nature protection & Natuur and Milieu (Nature and Environment) \\
& Vogelbescherming Nederland (Dutch Bird Protection) \\
\hline
\end{tabular}

On the 10 February 2020, the negotiators' agreement of the North Sea Agreement was sent to parliament, where the finalized agreement was presented on the 19 June 2020 . The proposed solutions to settle the divergent claims for space on the North Sea involve three transitions related to the North Sea, in the areas of: (1) food; (2) energy; (3) nature.

With regards to food-related issues, the fishery sector needs to be "reoriented and restructured", as this is of ecological necessity and an "(business) economic reality" [7]. Additionally, there is a social component, as the people working in the fishing industry need a clear perspective on their future. A transition fund of 200 million euros was set, of which 119 million euros will be used for reorganizing and innovating the fishing fleet, with a focus on buying out the fishers and reducing the fleet. The space allowed for fishing is reduced. The main method of fishing is trawler fishing. In wind parks, this is considered unsafe as the trawls can damage the electricity cables, while in ecologically sensitive areas it is generally regarded as too damaging to be allowed there.

On matters related to energy, the North Sea agreement adopts the term used in the Climate Agreement, the Green Powerhouse North Sea. The government has decided to substantially expand offshore wind energy on the North Sea. Therefore, space has to be allocated to produce, store, and transport electricity, while requiring careful consideration of the tradeoffs between the other interests.

Regarding nature, the participants all agree on the importance of a 'healthy' North Sea. It is referred to as a 'commons' and a necessity for food, energy, and nature. However, to become healthy, recovery is necessary. Therefore, protected sea-floor areas will go from $0.3 \%$ to $15 \%$ (the European goal is $30 \%$ ). Ecologically important areas will be free from trawler fishing. Of the transition fund, 50 million goes to research on the North Sea's ecology and the different activities' effects on this [24].

The North Sea Agreement acknowledged that stakeholders' interests in producing energy, securing a stable food supply, and conserving and restoring nature can be mutually exclusive, but that such conflicts must been dealt with in a "balanced" way [6]. Minister Van Nieuwenhuizen, the coordinator of this process, supports this claim and writes that the agreement has "broad support from the societal organizations that are intensively involved in the implementation of the Climate Agreement on the North Sea" [25].

In contrast with this apparent consensus, the public and political reception of the North Sea Agreement was more critical. If any consensus in the written media can be observed, it is that the interests of the fishers are not met well. A review article in a major Dutch newspaper stated that the fishing sector made more concessions than energy and nature sectors did [26]. An article in another major Dutch newspaper suggested that there was too much struggle between the interests of nature and fishing and too little between energy and nature. It presented the story of a fisher who argued that the fishing and nature sectors have been played out against each other, and that the negative environmental effects of the 
wind parks did not receive enough attention. A researcher from Wageningen University Off Shore Wind Research Domain was also quoted, who agreed with the potential for such negative effects, as a lot is uncertain regarding the impacts of the planned wind parks on sea life. Similarly, the research institute Deltares wrote that the wind parks will influence tides, waves, and currents, possibly limiting the distribution of nutrients in these areas, affecting sea mammals and fish yields [27].

Regarding the results of the agreements, most of the critique was focused on the prohibition of trawler fishing in newly protected areas. The Friese Front is such an area that is ecologically important due to its high biodiversity, although it is also a main zone for langoustine fishing. Critique on the closing of conservation areas is brought up in newspaper articles on the agreement [26,27], and in questions in the Parliament [28,29].

On the process of the North Sea Consultation, some fishers felt they were not represented by the right people, arguing that these representatives were unfamiliar with the practice of fishing, and lacked an understanding of the practical interests of the fishers [27]. Additionally, the parliamentary commission on I\&W posed the question as to whether fishers were not underrepresented. Moreover, this commission expressed concerns about the exclusion of important parties from the consultation like the maritime sector, shipping, coastal provinces and municipalities, military defense, sand extraction, the coast guard and the general public [28].

After these reactions to the negotiators' agreement, two adjustments were made in the final North Sea Agreement. The first was a sentence added on the common grounds of the participants, stating that in the common balance of interests, the interests of the fisheries have been taken into consideration as much as possible. The second was a concession to the fisheries. They were allowed to fish in a part of the Friese Front that is important for langoustine fishing. However, $1600 \mathrm{~m}^{2}$ of the area remains a protected 'no fishing zone' [6]. Additionally, in November that year, the minister said she is open to making concessions on fishing in another area, called Borkumse Stenen [30].

To make future decisions, the North Sea Consultation will be prolonged for at least two years, while a few adjustments will be made to meet the critiques on the agreement and first round of consultation. Firstly, the effects of wind parks on nature are to be investigated more thoroughly, especially the sound pollution from pile driving. Secondly, more sectors are to be represented, including a permanent seat for the shipping sector. Thirdly, the representation of the sectors in the North Sea Consultation will be more numerically balanced [30].

For a majority of the members of the fishing organizations, these adjustments were not sufficient. The fishers in the Vissersbond and Producers' Organization Urk, representing a majority of members of VisNed, the branch association for cutter fishers, did not approve of the agreement. Nevertheless, the cabinet and parliament kept supporting the North Sea Agreement and Consultation. In June 2020, the final agreement was reached, without the fishing sector. Thereafter, in September 2020, the fishers unanimously stepped out of the consultation. As reported, the fishers were critical of creating areas protected from fishing and of the limited means for the fleet's reorganization. In addition, they were internally divided on their approach to the consultation [31].

\section{Three Views on Health}

Within the context of the North Sea Consultation, 'health' is used to describe a desired state of the environment. The title and subtitle of the agreement are exemplary: The North Sea Agreement. Extra miles for a healthy North Sea. In the introduction, having a healthy sea is mentioned as a main goal, to which all other activities must adapt [6]. This goal is supported by the consultation's main institutional context. For instance, the Climate Agreement set six conditions for wind parks in the North Sea. One of these six is that the parks must stay within the conditions of "the carrying capacity of a healthy North Sea" [32]. Interviewees mentioned how this Climate Agreement was a main driver of the North Sea Consultation, serving as an outline and starting point for the North Sea 
Agreement. Another institutional factor that the stakeholders saw as such a main influence is the biodiversity standard set by the European Commission, which states that at least 30\% of the EU's sea area must be protected by 2030. The European Commission communicates in its EU Biodiversity Strategy for 2030 that: "The commitments proposed in this strategy pave the way for ambitious and necessary changes - changes that will ensure the wellbeing and economic prosperity of present and future generations in a healthy environment" [24] (our italics added).

Thus, the health metaphor is strongly embedded within the institutional context of the North Sea Consultation, as the Climate Agreement and the European Commission both set a 'healthy environment' as a goal to achieve via their policies. The interviews gave rise to a more fine-grained picture of the interviewees' concepts of a 'healthy' North Sea. Figure 1 presents these findings. Two concepts of a healthy North Sea were identified and three proposed courses of action were found.

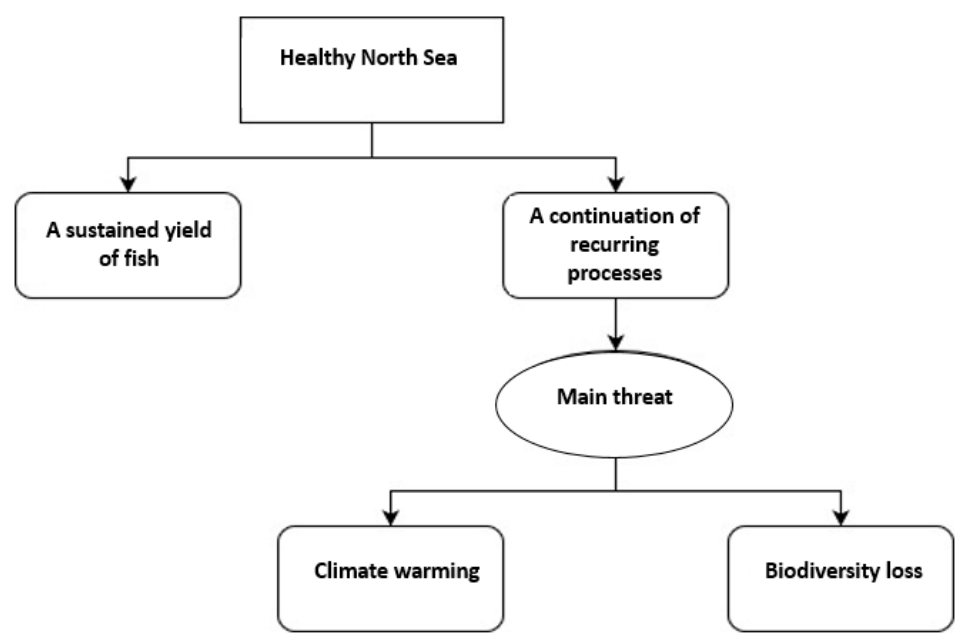

Figure 1. Three courses of action are supported by the desired health of the North Sea in the North Sea Consultation.

The first concept of a healthy sea, as forwarded by the Vissersbond and VisNed, is that the sea is able to provide a sustained yield of fish. For instance, when Pim Visser of VisNed was asked during the interview what he regarded as a healthy North Sea, he replied:

I think a healthy North Sea is something we can harvest healthily from for years to come. For the fishing sector, the maximum sustainable harvest is a concept: the principal remains intact, and we do not fish more than the interest on it. And that is a good starting point.

Secondly, there is the concept of health that sees a system of continuity and adaptation as a necessary condition for the sea's health. The NGOs Wereld Natuur Fonds (WNF), Stichting de Noordzee, and Greenpeace voice this view explicitly, to which the wind energy association NWEA and the ministry of agriculture, nature, and food quality (LNV) seem to comply, although less explicitly. In this view, there are some continuing processes in the ecosystems of the sea that must be maintained. For WNF, this means ensuring that every organism can eat and reproduce. As Jonna van Ulzen said:

I once had a biology teacher who said: 'Everything in nature is about sex and eating'. Of course, we also make estimations about what nature wants. But speaking of animals, they just want food, safety, and a place to live and reproduce. Hest:

For Stichting de Noordzee, the view on health is similar. According to its director Van

[T] The fishers think the North Sea is healthy when it has enough of the fish they want to catch. A conservationist, however, will look at the entire food web: 'Are there small fish, 
different kinds of fish, sharks, predatory fish?' While a fisher only looks at the fish he wants to catch. In this case, this is usually plaice and sole. Therefore, if plaice and sole are doing well, a fisher will say: 'So the sea is healthy.' We have a much more holistic approach to that.

He further describes that Stichting de Noordzee sees the health of the North Sea "that it is not a point, although much more a process". A healthy sea "is a system that changes, both due to climate change and humanity, and what you want to preserve is that that system can continue to develop itself", which is a "moving target".

Stakeholders indicated that it is very difficult to know what exactly an essential component of this system of continuity is, which should remain intact. Broadly, there are two ways to view this, namely a-historic and historic approaches. Van Hest argues against the latter:

What conservationists often do, is that they go to the past. But then I sometimes jokingly say: 'So, if you go back 10,000 years, you will see that the North Sea is a tundra, a tundra with mammoths. Therefore, a healthy North Sea would be a plain tundra with mammoths'. Other people say: 'No, a healthy North Sea is what it was like before the industrial revolution when there were still those big oyster reefs'.

Instead of determining a point in the past to see what must remain, Van Hest wants the current processes of adaptation to remain intact. For this, there is a set of indicators as established by the European Commission. For instance. these include a stable population of fish, the presence of some biogenic structures, and clean water. As long as these indicators remain stable, human influences are not necessarily considered to be bad.

Other parties do view historical elements in the North Sea as necessities for a healthy North Sea. For instance, Timmers of NWEA mentions that there used to be many oyster reefs in the North Sea before mechanical fishing made its appearance, and that the purpose of the conservation areas is to bring these back, "so that the sea can recover, as it originally was".

The concept of health as protecting some reproducing elements and processes is held by these stakeholders. However, all stakeholders state that knowing what specifically to protect to keep this system of continuity functioning is difficult, as ecosystems are notoriously complex and difficult to fully understand. Therefore, from the positive description of essential systems in the North Sea, nature protection becomes the focus for preventing damage to these systems. WNF's Van Ulzen stated this when talking about working for nature conservation:

Some people really think you are either counting birds all day or that you work in some sort of animal shelter. I say: 'Yes, we can fill all of nature with feeders and nesting boxes, but actually when you protect nature and wildife, you do that by protecting the habitat. When you look at rivers, it is important that the river can flow freely and that you don't put dams in it'. So basically, if you give nature its space, just real space, then nature will take care of itself. Nature conservation is actually limiting harmful human influences.

Additionally, she makes two things clear. First, the conditions for keeping the system intact often lie in entire habitats. Therefore, nature conservation will often focus on keeping the habitats of organisms intact. Second, nature conservation focuses more on reducing harm than on specifically promoting the positive aspects of the system.

There are conflicting views, however, on what causes the biggest threat to the health of the North Sea. As Van Ulzen says:

There are, of course, many green parties, and they are often lumped together, but actually, there are the biodiversity parties, which are very committed to the biodiversity crisis ... and there are the parties that are committed to the climate crisis.

Other stakeholders also mentioned this conflict in prioritizing nature conservation measures. While both the biodiversity crisis and the climate crisis threaten the health of the North Sea, measures such as wind turbines can reduce the harm of the changing climate 
while increasing the severity of the biodiversity crisis. Therefore, in their appreciation of the wind parks, the stakeholders aiming to protect the health of the North Sea make clear which of these two crises they see as the biggest threat.

The parties that prioritize the mitigation of the climate crisis are Stichting de Noordzee, NWEA, and Greenpeace. For instance, Hans Timmers says: "What is a healthy North Sea? What is a good definition? ... The biggest risk for a wrong ecosystem is, of course, the warming seas". Hilde Stroot of Greenpeace says:

Looking at the urgency of the climate problem, in which we have less than 10 years to fix it, Greenpeace believes that we must maximize the roll-out of wind at sea. In doing so we should limit the damage it does. But waiting is the last thing we should do right now.

The parties that focus more on averting the biodiversity crisis are WNF and Vogelbescherming. Van Ulzen illustrates WNF's position by saying:

Well, we will never deny the climate crisis—we also want to achieve the Paris goals-but not at the expense of biodiversity and nature. Therefore, the moment you say, 'we have to achieve those climate goals, so build all those nature reserves full of wind turbines', you are kind of throwing the baby out with the bathwater.

As she mentions that harming biodiversity too much by placing wind parks is counterproductive in protecting nature, she makes clear that biodiversity loss is more fundamental to nature conservation than the climate crisis.

In sum, the stakeholders hold two concepts, divided into three views on what they see as a healthy North Sea. The fishing sector regards it as the ability to have a sustained yield. The other sectors see a healthy North Sea as one where certain processes can keep reproducing themselves. It is difficult to say what elements of these systems must then be able to reproduce, as stakeholders are divided into more historic or non-historic views. Likewise, it is difficult to see what elements in an ecosystem (will) be essential for the continuation of the system. Therefore, there is a focus on protecting the ecosystem's habitats from harm. This group of sectors is then divided on what harm should be prioritized; either aiming to limit the climate crisis or to combat the biodiversity crisis. Thus, broadly, there are three courses of action inspired by the desired health of the North Sea in the North Sea Consultation: sustained yield, limiting the biodiversity crisis, and limiting the climate crisis.

\section{Conflicting Views}

The diverging views on health give rise to the stakeholders' different positions on trawler fishing, conservation areas, and wind parks- the North Sea Agreement's main foci. Firstly, the two concepts of health support conflicting judgments on the effects of trawler fishing on the sea's health, and thereby on its desirability. For example, a fishing boat drags a trawl along the bottom of the ocean when trawling. This is harmful to some organisms on the seafloor, although not to all. The fishing nets, chains, and trawls can damage oyster or worm reefs by disturbing the sea's soil. Additionally, the method sees high levels of bycatch. For example, until 2014, conventional tickler chain beam trawling generated average discard rates of more than $50 \%$ when fishing for plaice in the Dutch North Sea, one of the mainly targeted fish species there [33]. Most discarded fish are undersized, of which the vast majority do not survive [34]. However, the method does not only negatively affect sea life. Regarding plaice again, it is suggested that trawling results in higher population levels, as the species grows well in the loose sandy seafloor that results from trawling. This can increase a fisher's yields, so they can argue that the sea becomes healthier because of the trawling activities.

The other stakeholders, however, consider a sea with trawling less healthy, as the elements of the North Sea that they see as essential to its ecosystem are damaged by it. Van Hest illustrates the different understandings on health and trawler fishing:

[T]hose soles and plaices, they do well when you disturb the seafloor. Because if the bottom is disturbed, sediment is released, and worms can develop faster. That is still a 
hypothesis, but quite a strong one... This allows the worms to develop faster, and there is more food for plaice and soles. Therefore, these species happen to benefit from being churned up. We, however, say: 'Okay, nice for those species, but not good at all for a lot of other species, like the ones that grow slower, or reef-forming structures'.

Other sectors hold similar views on trawler fishing. Therefore, the fishing sector and most other stakeholders view the desirability of trawler fishing differently, supported by their different concepts of health.

Secondly, these different understandings of health divide the judgments of the stakeholders in a similar way when considering the number of conservation areas. As mentioned above, the North Sea Agreement states that 15\% of the North Sea should be protected by 2030 , not mentioning any seasonal use, although European rules aim at having 30\% protected. Using the concept of health as presented by the fishers, these (amounts of) conservation areas are not necessary, as sustaining stocks of plaice and soles can cohere well with all kinds of human activities, and they might even benefit from it. Nooitgedagt, chair of the Vissersbond, says it like this:

So just the fact that was said - that is how it started-'We want to make conservation areas, and we want to make fishing areas'. Marine Protected Areas and Fishery Protected Areas, FPAs and MPAs. That already creates an apparent contradiction between two worlds, like 'okay, okay, so if we fish in a nature reserve, we will destroy the thing.' That is surely a wrong thought.

Nooitgedagt makes clear that in the North Sea Consultation a contradiction was created between nature's interests and fishing's interests, while in principle there is no conflict between nature conservation and fishing he says. The view on health that the fishing sector holds does not fit well with keeping human activity out of the conservation areas. Therefore, they do not see the need for more conservation areas-these are merely hindering 'closed areas' as Visser and Nooitgedagt labeled them. In line with this, they indicated that having fewer of such areas is one of the policies that may make the producers' organization Urk and the Vissersbond support the North Sea Consultation again.

In the other concept of health, closed conservation areas are essential to the North Sea's health. Van Hest says for instance:

[W]hen you talk about the amount of bottom that is protected from bottom-disturbing

fishing, it is currently, in 2021,0.3\%. That really is very little ... . While for a healthy ecosystem, you absolutely must leave certain parts of the soil alone.

Other stakeholders display similar views. They agree that the conservation areas are necessary, and most would like to see more than $15 \%$ protected. This is a necessity for the health of the sea they say.

A third example of how the different views of health support conflicting moral views concerns the desirability of wind parks. Here, the stakeholders that uphold the concept of health as 'protecting processes of continuation' differ in their valuation of the parks. For the stakeholders that are focused on the climate crisis, the wind parks feel like a necessity. As Van Hest says: "These wind parks just need to be here". Stroot makes Greenpeace's position on wind parks clear, as she says:

We must deploy wind power as much as possible, while carefully monitoring and adjusting its effects .... Yes, it poses large risks, but we cannot wait until the problem becomes so urgent that it cannot be solved anymore.

These stakeholders consider the climate crisis as the biggest threat to the health of the North Sea, supporting a fast roll-out of wind parks on the North Sea. For other parties, however, loss of biodiversity is seen as the biggest threat. As Van Ulzen said and was quoted above, the climate goals should not harm nature too much. Stichting de Noordzee feels these nature protection conflicts internally. As Van Hest said:

We want a lot more sustainable energy, which is very badly needed to solve the climate problem. But these wind turbines also have negative effects on birds, at least on most 
bird species, and on marine life, if you do not get it right. So yes, we feel that conflict internally, very much.

Additionally, the representatives of the fishing sector note how some fishers see wind parks mainly as a blockage. As Nooitgedagt said:

You cannot fish where those turbines are placed. Well, you can fish there, but only with a fishing rod and very small boats, but you cannot go there with a trawl. You should not want that either, because then there will just be accidents.

As representatives of this sector, Visser and Nooitgedagt do not oppose the placement of wind parks altogether. They take the development of wind parks as a 'given', to which the fishing sector must adapt. The North Sea Consultation was ultimately not about whether the wind parks will be there, although to agree on "where are how many placed, and when? It's more of a planning discussion than a yes/no discussion", as Visser said. He feels that the fishing sector must adapt to this context. At least a part of the fishers sees the wind parks as a threat, as a hindrance to what they want to do. The representatives of the sector do not necessarily feel this way, as they see the societal call for the parks. However, this does not mean they support the parks.

For instance, Visser spoke out against the parks because of the uncertain environmental effects of placing so many of them. He mentions changes in currents, silt depositions, highand low-pressure areas, and weather systems, which are predicted in environmental models, for instance by Deltares. The risks of these effects are too large, which is why the building of wind parks as in the plans that are now proposed in the North Sea Consultation cannot be justified. Visser, thus, calls for building the wind parks at a slower pace than what is happening now. Such environmental effects form a threat to a healthy sea, with 'health' meaning a sustained yield. These environmental effects could alter those yields, since upwelling and nutrient flows depend on the currents and tides as they are now.

Additionally, when combining wind parks with seaweed farms, the fishing sector is afraid of nutrient competition between the farms and the fish they want to catch. Nooitgedagt states:

In fact, when those wind farms come and we don't fish in them with trawlers, but we grow oysters, mussels, or seaweed, for example ... you will see that concessions will be given to the highest bidder... . Because seaweed... will be the business of the future. Well, they were cheering sky high because all will be filled with seaweed.

I said: 'Have you ever thought about food competition?' For instance, if there is a large seaweed park in front of the Oosterschelde, the mussels that lie on the Oosterschelde... will have food shortages and lose weight laying there. Because it all must eat from the same sea.

Thus, in addition to the direct environmental effects of the wind parks, the fishing sector also foresees negative environmental effects of the multiple uses of space in the wind parks, in this case by seaweed production. These environmental effects are harmful because they limit the potential for sustaining the catch from the sea, as Nooitgedagt mentions in the case of the Oosterschelde mussel production.

Altogether, the three views of health support the different normative judgments that stakeholders hold on the three major outcomes of the North Sea Consultation. In Figure 2, the relations between the stakeholders and their views on health are shown. The two concepts of health and the discussion on what the biggest threat is support the different positions the stakeholders hold on these topics. 


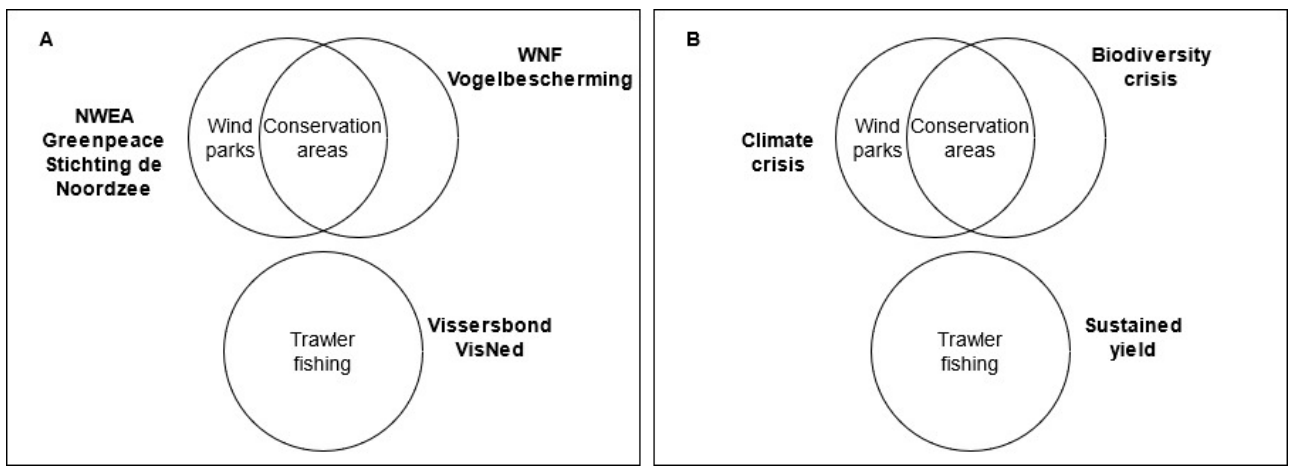

Figure 2. Different views on health that support different normative positions. (A). Each circle represents a stakeholder or groups of stakeholder and their proximity to the topics they find most important. (B). Each circle represents a view of health and the proximity to the topics.

These different views on the sea's health are not evenly aligned with intuitive concepts of 'health', as the concept 'health' implies that there is a 'body' that must be healthy. When speaking of a healthy ecosystem, surely there is 'something vital' that must be protected to be functioning well. Note that this attribute of the health metaphor is what appealed to environmental scientists, as they could make their claims to 'protect' certain areas, which resonates well with the public and policy-makers $[13,15]$. They use the health metaphor to talk about an ecosystem as a body that can be threatened, as a set of systems that must be kept free from disease to perform its functions [14]. Seeing the North Sea as a body that must remain healthy, it can for instance be threatened by warming seas, foreign bodies such as invasive species, or fishing activities, jeopardizing its authentic functions and systems that must be kept in order. This is considered differently in the fishers' concept of a healthy North Sea, as a sea that can provide a certain function, producing enough fish. In the fishers' concept of health, the ecosystem as a body is intuitively missing.

Indeed, from the beginning onwards, Nooitgedagt felt resistance to the common concept of health in the North Sea Deliberation. He felt that a view of health was presented that saw fishing as conflicting with it. He also wants a healthy North Sea and a sustainable future for it, he says. But then that chairman Wallage opened the North Sea Consultation by saying that he wanted the North Sea Consultation to focus on nature and sustainability, Nooitgedagt immediately felt reluctance, as he sees this concept not aligning to that of the fishers:

Then my reaction is: 'Guys, how do we start?' So, everything must be green, and pure. That is a completely different experience from the people that this is about. At these first steps, we already feel resistance.

And also, that science gets a very high position, where science... Well, that is often the 'green' science, where ecology and biology ... . Well, not for one thing or another, all of that has good intentions, I am not against that at all, but they are the predecessors of Stichting de Noordzee, Greenpeace, etc. Those are ultimately ... They do not say different things.... Then you are negotiating, as if you are an enemy.

As described above, he felt that an immediate confrontation was set up. He indicates that language plays a role in this, for instance saying: "With ... words a different atmosphere can be created. Use the right words, that don't contain these contradictions." Nooitgedagt experienced resistance to the fishing sector's concept of health from the beginning of the North Sea Consultation onwards, noting the importance of using the right words and articulating concerns regarding science's viewpoints on health.

Visser went further and contested one of the intuitive claims of health. For example, leaving a sick individual alone to rest is common sense, and this supports not entering the conservation areas in the sea, as stakeholders propose in the North Sea Consultation. He opposed this claim, saying: 
The situation as it was, the conditions as they were, these are no longer there. The water is warmer, the water has a different composition, there is less eutrophication, the water is clearer. A lot is going on. Therefore, it certainly is not clear that if you just do nothing, then what they call a 'pristine situation' will come back.

So as a fisher you have to admit: 'Guys, what we do has impact and we have to be careful about that, pay close attention'. And, as a nature conservationist, you have to say: 'Yeah guys, stopping human activity doesn't automatically mean it's going to be quite the way we think it should be'.

Visser contests the intuitive claim that the other stakeholders support, namely that having fewer human activities will automatically improve the 'health' of that area. Visser and Nooitgedagt do not mention the metaphor of health here, although point out problems they face with the concept of health as supported by the other stakeholders. They feel as if an unnecessary contradiction is set between nature goals and fishing activities, and that automatically it is assumed that having fewer human activities will improve the sea's health.

\section{Conclusions: Understanding the Normative Challenges of Metaphors}

In the North Sea Consultation, the metaphor of environmental health steers the conversation into accepting certain concepts of a 'good' state of the North Sea, which holds that recurring natural processes are to be continued and that the continuation of these processes should be secured. European and national policies can be said to follow this metaphor, as do the nature protection and wind energy sectors. Whereas this understanding of a healthy sea became dominant and was reproduced by most stakeholders, alternative concepts and alternative metaphors are disregarded. Indeed, the fishing sector has difficulties with the metaphor of a healthy sea and by forcing its representatives to adopt it; they had to stretch its meaning, portraying a 'healthy' sea as one that provides a sustained yield of fish. This way of seeing would have fitted much better with an agricultural metaphor, which according to Nadasny [35] implies stewardship and an expectation of yields to proliferate. This fit is also underlined by Visser's concept of health as a sustained yield:

I think a healthy North Sea is something we can harvest healthily from for years to come. For the fishing sector, the maximum sustainable harvest is a concept-the principle remains intact, and we do not fish more than we are interested in. And that is a good starting point.

This analysis of the North Sea Consultation illustrates that different interpretations of metaphors are not only semantic differences. Metaphors exert power over a deliberative process and they come with particular normative implications. Above all, they have exclusionary effects, which is undesirable not because the fishers may be right, but because it closes down the political debate, thereby discarding alternative metaphors that also may have leverage (cf. [36]). We can avoid the use of metaphors in politics, although in a debate that is democratic, alternative metaphors, such as the one representing the sea as farmland, should at least be given the chance to be discussed.

In other words, it might seem that the actors agreed on the solutions that have been selected to address their use of the North Sea, although this agreement is partial at most. Some of the actors simply were not able to discuss the desirability of solutions on their own terms. Moreover, the North Sea Consultation only included actors representing a narrow set of interest groups, which also qualifies the societal legitimacy of the agreement that followed out of this process. Indeed, metaphors reduce the complexity, while wicked problems deepen the complexity, necessitating a detailed analysis of all actors that are involved, as well as the problem definitions for these actors. This would allow decisionmaking based on a comprehensive-instead of a partial-understanding of the problem at hand (also see [37]).

In policy sciences, the role of discursive power is usually taken as a given that is unproblematic in itself. We consider it illustrative how the concept of 'frames' is used in 
policy sciences. To a large extent, this notion by Rein and Schön [38] overlaps with that of 'metaphors'. Although 'frames' are used often, we opted for 'metaphors', not only because it points us more straightforwardly and intuitively to the fact that a metaphor aims to make sense of a phenomenon in an indirect way (although 'metaphor' is the same, as 'framing' itself is also a metaphor, with the original Greek meaning being 'something that carries'), but above all because in policy sciences, 'framing' is usually portrayed as a strategic activity in which political actors aim to create a picture of reality that serves their political goals. This emphasis on strategic considerations obscures the moral connotations of frames, while it has precisely been the aim of this paper to articulate these moral connotations.

Determining the dominant metaphor or frame is seen as a successful form of political agenda-setting, which is simply what a political entrepreneur is expected to do. This may be so if all actors have the same chance to set the agenda and if the rules of the game are agreed upon and create a level playing field. In the case of the North Sea Consultation, such a level playing field was not there. There is a big difference between the energy sector, for which the outcome of the consultation process does not affect its identity, and the fishing industry, and to a lesser extent also to the environmental NGOs, which are financially, emotionally, and culturally connected to the North Sea. As such, coming to an agreement is not just a 'game' - one of the most loved metaphors of policy-makers to describe their work - as the fishers have everything to lose.

It is safe to say that the course of events in the North Sea Consultation will be typical for many future decision-making processes with regards to climate adaptation. We may distinguish three key issues here. First, as mentioned earlier, metaphors play a decisive role in the discourse on climate adaptation, limiting the access of certain normative positions in political deliberation. Second, a level playing field cannot be expected, as climate adaptation measures will have serious consequences for a wide range of actors, many of whom may not have the necessary resources, such as access to expertise and actors with political leverage. Third, this uneven distribution of impact and resources is reinforced by the dependency of parties on the outcomes of these measures-especially vulnerable people have connected their identity to professions and practices that may have to be given up.

As stated in the introduction, wicked problems are moral in their very nature and climate adaptation policies are no exception. Engaging a wide range of actors in deliberation to address wicked problems is necessary to create solutions that are effective and acceptable - even if they will only be 'clumsy' (that is, conditional and temporary) solutions [39]. However, the inevitable use of metaphors in this deliberation will affect its democratic and moral efficacy, as they invoke power differences.

We do not necessarily take a Foucauldian view by stating that all power is discursive, although as is also manifested in our case, institutional and discursive power tend to reinforce each other-actors with the right resources are prone to also display discursive power. In this, it may be naïve to think that power differences can be nullified. However, what can be done first is that metaphors are recognized as metaphors. This raises the awareness that a certain way of discussing a policy issue is not the only way, and as such opens up the possibility that alternative metaphors are taken seriously. Second, the moral connotations of metaphors need to be acknowledged, so that their role in a deliberative process is not seen as the mere input of a policy game, but as the willingness of actors to discuss policy measures that may impact their moral identity. If these moral connotations are not acknowledged, this willingness will disappear, and as with the fishers, actors will turn their backs to the political domain. Most importantly, and this is our third point, metaphors themselves should also be subjected to deliberation-only then we can engage with climate adaptation in a way that is democratic and just.

Author Contributions: The first author H.G. gathered the empirical data and created the first version of this study under supervision of other authors U.P., A.C. and B.T., which has subsequently been reworked into the current paper as a collaboration between all authors. All authors have read and agreed to the published version of the manuscript. 
Funding: This research received no external funding.

Institutional Review Board Statement: This research has been approved by the Human Research Ethics Committee of the Delft University of Technology. ID number 1910.

Informed Consent Statement: Informed consent was obtained from all subjects involved in the study.

Conflicts of Interest: The authors declare no conflict of interest.

\section{Appendix A}

Table A1. Topics of Moral Relevance Used to Structure the Interviews.

On the outcomes of the North Sea Agreement:

1. The relationships between the interests of the fishing, nature, and energy sectors;

2. The reorganization and adaptation of the fishing fleet;

3. The distribution and size of the transition fund;

4. The locations of the areas allocated for energy production (wind or gas), fishing, or nature.

\section{On the North Sea Agreement itself:}

5. The representation of fishing, nature, and energy sectors;

6. The choice for the central role of these three sectors;

7. The relations between the representatives of these three sectors;

8. The interests of those participants not represented in the consultation process;

9. The consultation and participation of citizens.

\section{Appendix B}

Table A2. Interviewed Respondents.

\begin{tabular}{|c|c|c|}
\hline Domain & Actor & Role \\
\hline Government & Johan Osinga & $\begin{array}{l}\text { Director-general at the } \\
\text { Ministry LNV }\end{array}$ \\
\hline Energy & $\begin{array}{l}\text { Hans Timmers } \\
\text { Jo Peters }\end{array}$ & $\begin{array}{c}\text { Chair of NWEA } \\
\text { Chair and director of } \\
\text { NOGEPA }\end{array}$ \\
\hline Fishery & $\begin{array}{c}\text { Pim Visser } \\
\text { Johan Nooitgedagt }\end{array}$ & $\begin{array}{l}\text { Chair of VisNed } \\
\text { Chair and director of } \\
\text { Nederlandse Vissersbond } \\
\text { Director of Stichting de }\end{array}$ \\
\hline Nature & $\begin{array}{l}\text { Floris van Hest } \\
\text { Jonna van Ulzen } \\
\text { Hilde Stroot }\end{array}$ & $\begin{array}{c}\text { Noordzee } \\
\text { Senior Advisor Oceans at } \\
\text { WNF } \\
\text { Head Biodiversity and } \\
\text { Program Director at } \\
\text { Greenpeace Nederland }\end{array}$ \\
\hline
\end{tabular}

\section{References}

1. Rittel, H.W.J.; Webber, M.M. Dilemmas in a general theory of planning. Policy Sci. 1973, 4, 155-169. [CrossRef]

2. Pesch, U.; Vermaas, P.E. The Wickedness of Rittel and Webber's Dilemmas. Adm. Soc. 2020, 52, 960-979. [CrossRef]

3. Taebi, B.; Kwakkel, J.H.; Kermisch, C. Governing climate risks in the face of normative uncertainties. Wiley Interdiscip. Rev. Clim. Chang. 2020, 11, e666. [CrossRef]

4. Markowitz, E.M.; Shariff, A.F. Climate change and moral judgement. Nat. Clim. Chang. 2012, 2, 243. [CrossRef]

5. Rawls, J. A Theory of Justice; Harvard University Press: Cambridge, MA, USA, 2009.

6. Doorn, N.; Taebi, B. Rawls's Wide Reflective Equilibrium as a method for engaged interdisciplinary collaboration: Potentials and limitations for the context of technological risks. Sci. Technol. Hum. Values 2018, 43, 487-517. [CrossRef] [PubMed]

7. Overlegorgaan Fysieke Leefomgeving. Het Akkoord voor de Noordzee; OFL: The Hague, The Netherlands, 2020.

8. Van Hoof, L.; Steins, N.A.; Smith, S.; Kraan, M. Change as a permanent condition: A history of transition processes in Dutch North Sea fisheries. Mar. Policy 2020, 122, 104245. [CrossRef]

9. Lakoff, G.; Johnson, M. Metaphors We Live By; University of Chicago Press: Chicago, IL, USA, 2008. 
10. Hills, D. Metaphor. Available online: https://plato.stanford.edu/archives/fall2017/entries/metaphor/ (accessed on 28 June 2021).

11. Doorn, N.; Brackel, L.; Vermeulen, S. Distributing Responsibilities for Climate Adaptation: Examples from the Water Domain. Sustainability 2021, 13, 3676. [CrossRef]

12. IPCC. Managing the Risks of Extreme Events and Disasters to Advance Climate Change Adaptation; IPCC: Geneva, Switzerland, 2012.

13. Ross, N.; Eyles, J.; Cole, D.; Iannantuono, A. The ecosystem health metaphor in science and policy. Can. Geogr./Le Géographe Can. 1997, 41, 114-127. [CrossRef]

14. Mallee, H. The evolution of health as an ecological concept. Curr. Opin. Environ. Sustain. 2017, 25, 28-32. [CrossRef]

15. Franke, A.; Blenckner, T.; Duarte, C.M.; Ott, K.; Fleming, L.E.; Antia, A.; Reusch, T.B.; Bertram, C.; Hein, J.; Kronfeld-Goharani, U. Operationalizing Ocean Health: Toward integrated research on ocean health and recovery to achieve ocean sustainability. One Earth 2020, 2, 557-565. [CrossRef]

16. Karr, J.R. Defining and measuring river health. Freshw. Biol. 1999, 41, 221-234. [CrossRef]

17. Cormier, R.; Elliott, M. SMART marine goals, targets and management-is SDG 14 operational or aspirational, is 'Life Below Water' sinking or swimming? Mar. Pollut. Bull. 2017, 123, 28-33. [CrossRef] [PubMed]

18. Blue, B. What's wrong with healthy rivers? Promise and practice in the search for a guiding ideal for freshwater management. Prog. Phys. Geogr. Earth Environ. 2018, 42, 462-477. [CrossRef]

19. Halpern, B.S. Building on a decade of the Ocean Health Index. One Earth 2020, 2, 30-33. [CrossRef]

20. Vrooman, J.; Schild, G.; Rodriguez, A.G.; Van Hest, F. Windparken op de Noordzee: Kansen en Risico's voor de Natuur; Stichting de Noordzee: Utrecht, The Netherlands, 2018.

21. TKI Wind op Zee. The Netherlands' Long-Term Offshore Wind R \& D Agenda; TKI Wind op Zee: Utrecht, The Netherlands, 2019.

22. Wallage, J. Verkenning Noordzeestrategie 2030; Overlegorgaan Fysieke Leefomgeving: Den Haag, The Netherlands, 2018.

23. Van Nieuwenhuizen-Wijbenga, C. Verzoek aan OFL Tot opzetten van een Noordzeeoverleg; Ministry of Infrastructure and Water Management: Utrecht, The Netherlands, 2019.

24. European Commission. Communication from the Commission to the European Parliament, the Council, the European Economic and Social Committee and the Committee of the Regions, EU Biodiversity Strategy for 2030; EU: Brussels, Belgium, 2020.

25. Van Nieuwenhuizen-Wijbenga, C. Kamerbrief Akkoord voor de Noordzee; Ministry of Infrastructure and Water Management: Utrecht, The Netherlands, 2020.

26. Hofs, Y. Bruinvis vecht met windmolenbouwer en garnalenvisser om plekje in de Noordzee. De Volkskrant, 11 February 2020.

27. Goudsmit, R. Visserman Dirk Kraak: Ik ben gewoon zó bang om alles kwijt te raken. Trouw, 3 March 2020.

28. Mulder, A.; Schuurkamp, B. Onderhandelaarsakkoord voor de Noordzee. Lijst van vragen en antwoorden; Ministry of Infrastructure and Water Management: Utrecht, The Netherlands, 2020.

29. Van Nieuwenhuizen-Wijbenga, C. Beantwoording vragen Schriftelijk Overleg Onderhandelaarsakkoord voor de Noordzee; Ministry of Infrastructure and Water Management: Utrecht, The Netherlands, 2020.

30. Van Nieuwenhuizen-Wijbenga, C.; Schouten, C. Appreciatie van de adviezen over de governance van het Noordzeeoverleg en deelname van de visserijsector; Ministry of Infrastructure and Water Management: Utrecht, The Netherlands, 2020.

31. Joustra, T. Advies over de relatie tussen de visserij en het Noordzeeoverleg; Rijksoverheid: The Hague, The Netherlands, 2020.

32. Schram, E.; Molenaar, P.; Kleppe, R.; Rijnsdorp, A. Condition and Survival of Discards in Tickler Chain Beam Trawl Fisheries; Wageningen Marine Research: Yerseke, The Netherlands, 2020.

33. Rijksoverheid. Klimaatakkoord; Rijksoverheid: The Hague, The Netherlands, 2019.

34. Quirijns, F.; Turenhout, M.; Paijmans, A.; Taal, K. Factsheet: Pulse trawl; Wageningen University \& Research: Wageningen, The Netherlands, 2014.

35. Nadasdy, P. “We Don't Harvest Animals; We Kill Them”: Agricultural Metaphors and the Politics of Wildlife Management in the Yukon. In Knowing Nature; University of Chicago Press: Chicago, IL, USA, 2011; pp. 135-151.

36. Stirling, A. "Opening Up" and "Closing Down" Power, Participation, and Pluralism in the Social Appraisal of Technology. Sci. Technol. Hum. Values 2008, 33, 262-294. [CrossRef]

37. Escalera-Reyes, J. Public Participation and Socioecological Resilience. Hum. Dimens. Ecol. Restor. 2011, 79-92. [CrossRef]

38. Rein, M.; Schön, D. Frame-reflective policy discourse. Soc. Sci. Mod. States 1991, 9, 262-289.

39. Verweij, M.; Douglas, M.; Ellis, R.; Engel, C.; Hendriks, F.; Lohmann, S.; Ney, S.; Rayner, S.; Thompson, M. Clumsy solutions for a complex world: The case of climate change. Public Adm. 2006, 84, 817-843. [CrossRef] 